\title{
Carapace length-frequency distribution and carapace length- weight correlation of ornate spiny lobster (Panulirus ornatus) in Sebatik Island Waters - Indonesia
}

\author{
Wahyu Muzammil ${ }^{1,2 *}$, and Bambang Kurniadi ${ }^{3}$ \\ ${ }^{1}$ Aquatic Resources Management Department, Faculty of Marine Science and Fisheries, Raja Ali Haji Maritime University, \\ Indonesia \\ ${ }^{2}$ Marine Biotechnology Laboratory, Raja Ali Haji Maritime University, Indonesia \\ ${ }^{3}$ Aquatic Resources Management Department, Faculty of Agriculture, Tanjungpura University, Indonesia
}

\begin{abstract}
Ornate spiny lobster (Panulirus ornatus) in Sebatik Island is a commercial fisheries commodity that has the highest price if we compare it with another lobster caught by the fisherman in Sebatik Island Waters. That causes the effort to catch this lobster to increase continuously. The availability of biological aspects data of ornate spiny lobster is needed as a basis for sustainable lobster resource management in Sebatik Island. This research aims to analyze the biological performance of ornate spiny lobster in Sebatik Waters, coverage from study carapace length-frequency distribution and carapace length-weight correlation of ornate spiny lobster. This research is expected to provide benefits as basic information in lobster management. Information related to the biological condition of lobsters can be used as a consideration in strategies for the utilization and management of lobster resources. Measurement of carapace length, weight, and sex of ornate spiny lobster was carried out from April to August 2016 at lobster landing base in Sebatik Island, North Borneo, Indonesia. The results showed that the sex ratio shows an unstable ratio. The distribution catch size of ornate spiny lobsters ranged from $64.5-114.5 \mathrm{mmCL}$. The growth pattern of female and male ornate spiny lobsters was negative allometric with $\mathrm{r}$ and $\mathrm{R}^{2}$ values of both female and male $>0.95$. Carapace length at first ornate spiny lobster catch was $71.28 \mathrm{mmCL}$.
\end{abstract}

Keywords: Growth pattern, ornate spiny lobster, Sebatik Island waters, size distribution

\section{Introduction}

Indonesia has a high level of endemicity and diversity of lobster species with 19 species of lobster known genus of Panulirus which have high commercial value among other crustacean or fisheries commodities $^{1,2,3,4,5,6}$. Indonesia is a hotspot for lobster biodiversity, and Sebatik Island Waters is one of them ${ }^{7,8,9}$. Lobster (Panulirus spp) is known by local communities in Sebatik Island as udang karang or udang barong, because there find and catch this commodity in coral areas. Various lobster commodities that catch in Sebatik Island waters are mud spiny lobster (Panulirus polyphagus) known by local people as lobster pakistan, painted green/bamboo lobster (Panulirus versicolor) known as lobster bambu, scalloped spiny lobster (Panulirus homarus) known as lobster pasir, pronghor lobster (Panulirus penicillatus) known as lobster batu, and white-whiskered coral crayfish (Panulirus longipes femoristriga) known as lobster batik merah, and ornate spiny lobster (Panulirus ornatus) known as lobster mutiara. Ornate spiny lobster (Panulirus ornatus) is the most expensive lobster in Sebatik Island. Gill nets, fish pot trap (bubu), and handline are common fishing gear used by fishermen to lobster. Fishermen prefer to use gill nets, and dominant fishing gear used by fishers to catch lobster on Sebatik Island waters. Fishermen in Sebatik Island catch various lobster, ornate spiny lobster not only the most expensive one but also the second most catch after mud spiny lobster.

Lobster (Panulirus spp) is a hot commodity and high-end seafood because of the increase of continuous market demand, while the fisheries production remains static $^{10,11,12}$. Consumer/market demand and high prices are expected to lead to an increase in a lobster catch. Pakistan lobster in Sebatik Island waters is the dominant lobster and has high economic value, so it has been exploited intensively ${ }^{13}$. The estimated exploitation rate of lobster leads to overfishing ${ }^{14}$.

The importance of ornate spiny lobster resource is not followed by data availability on biological aspects such as sex ratio, carapace length-frequency distribution, and carapace length-weight correlation of ornate spiny lobster. Therefore, it is all needed as a basis for sustainable lobster resource management on Sebatik Island waters. This research aims to analyze the biological performance of ornate spiny lobster in

* Corresponding author: wahyu.muzammil@umrah.ac.id 
Sebatik Waters, North Borneo Province. Analysis of study carapace length-frequency distribution and carapace length-weight correlations of ornate spiny lobster in Sebatik Island waters, Indonesia. This research is expected to provide benefits as basic information in lobster management. Information related to the biological condition of lobsters can be used as a consideration in strategies for the utilization and management of lobster resources in a sustainable manner.

\section{Methods}

Ornate spiny lobster caught by fishers collected in the landing site of lobster in three main landing bases in Sebatik Island. The research locations are in landing sites lobster of Sebatik Island (Figure 1). Ornate spiny lobster biology data collection was implemented from April to August 2016. Observation of ornate spiny lobster samples included sex determination, carapace length, and weight every month. The length of the carapace was measured using a caliper with an accuracy of $1 \mathrm{~mm}$. Weight measurement using a digital scale with an accuracy of $0.1 \mathrm{~g}$.

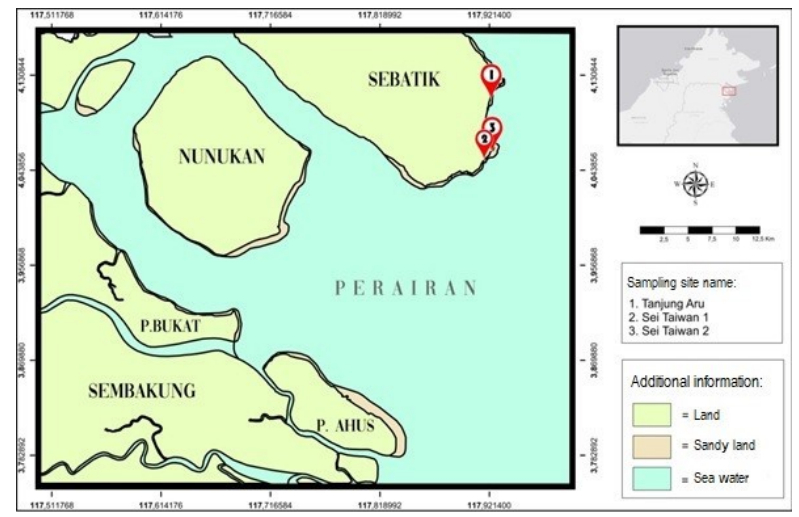

Fig. 1. Sampling site.

\subsection{Sex ratio analysis}

The sexual of male and female ornate spiny lobster are differentiated through secondary sex traits, which was done by visually observing their thelicum hairs by Wirosaputro (1996)15. Calculations for sex ratio is based on the following: $\mathrm{NK}=\mathrm{Nbi} / \mathrm{Nji}$, where:

$\mathrm{NK}=$ sex ratio

$\mathrm{Nbi}=$ number of female ornate spiny lobster of the ith size group

$\mathrm{Nji}=$ number of male ornate spiny lobster of the ith size group

Testing on the sex ratio was done using a chi-square test16:

where:

$$
X^{2}=\sum_{i=1}^{k} \frac{(o i-e i)^{2}}{e i}
$$

oi $=$ frequency number of male and female ornate spiny lobster

ei $=$ predicted number of male and female ornate spiny lobster in the ith range

$\mathrm{k}=$ observation station group for observed ornate spiny lobster

\subsection{Carapace length (CL)-Weight Analysis}

Analysis of the correlation between carapace length and weight of ornate spiny lobster was used to determine the growth pattern. The equation used is as follows (Jennings et al. 2001; King 1995)17,18:

$\mathrm{W}=\mathrm{aLb}$

Where $\mathrm{W}$ is the wet weight $(\mathrm{g}), \mathrm{L}$ is carapace length $(\mathrm{mm}), \mathrm{a}$ is the intercept, and $\mathrm{b}$ is the growth pattern estimator (regression coefficient). The frequency distribution was obtained by tabulating carapace length with class intervals. The first catch of ornate spiny lobster size carapace length (Lc) was obtained through a logistic function approach with the following equation (Sparre \& Venema, 1992)19:

$S_{L}=\frac{1}{1+\exp (S 1-S 2 \times C)} ; \ln \frac{1}{S_{L}}-1=S 1-S 2 \times L$ Where SL is the logistic curve, S1 and S2 are constants in the logistic curve equation.

\section{Result}

\subsection{Sex ratio}

The total sample of ornate spiny lobster obtained from April to August 2016 was 52 samples, a female sample compared to male sample composition of 19:33 respectively. The female-male sex ratio of ornate spiny lobster in Sebatik Island waters is 1:1.74. Based on a Chi-square test with a $95 \%$ confidence level $(\alpha=0,05)$, the female-male sex ratio is generally in an unstable condition (Figure 2).

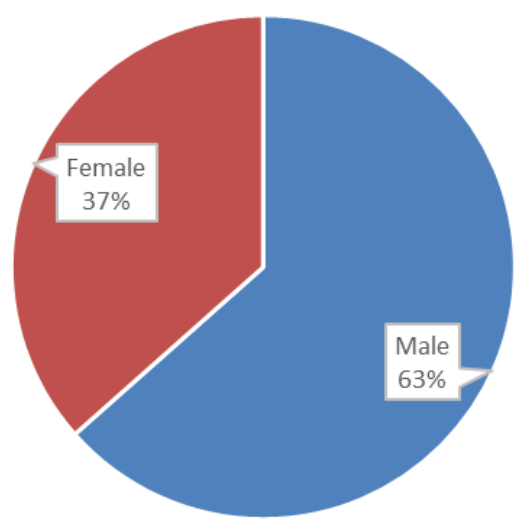

Figure 2. The sexual ratio of ornate spiny lobster (Panulirus ornatus) in Sebatik Island waters

\subsection{Carapace length distribution}

Ornate spiny lobster is one of the most economically important fisheries commodites in Indonesia, like blue swimming crab, mud crab, mantis shrimps, and snapper fish $\mathrm{h}^{3,5,6,20,21}$. The carapace length of ornate spiny lobster from Sebatik Island waters is between 64.6-111.6 mm, distribution from mean carapace length class $64.5-114.5$. The class mode of carapace length is found at the class median of $74.5 \mathrm{~mm}$. 
Size distribution of carapace length observed throughout the study is shown in Figure 3.

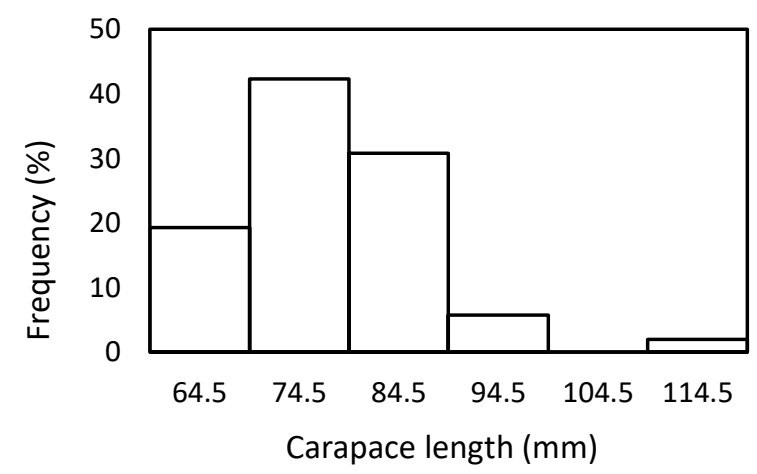

Figure 3. Carapace length-frequency of ornate spiny lobster (Panulirus ornatus)

\subsection{Carapace length-weight correlation}

Measurement variables for carapace length and ornate spiny lobster weight use biometric analysis from data compiled monthly. Analysis results were obtained from using the correlation between carapace length and weight of ornate spiny lobster with a determining coefficient $\left(\mathrm{r}^{2}\right)$ of $0.9753-0.9880$ for both males and females. Following a t-test, with a $95 \%$ confidence level $(\alpha=0.05)$, it was found that growth patterns for both female and male ornate spiny lobster are a negative allometric pattern. This shows that the increase of carapace length and weight of female and male ornate spiny lobster in Sebatik Island waters is not balanced (growth of carapace length is faster than their weight gain). The b-value (estimator for growth pattern) in this research shows 2.7747 for females and 2.8573 for males (Figure 4).
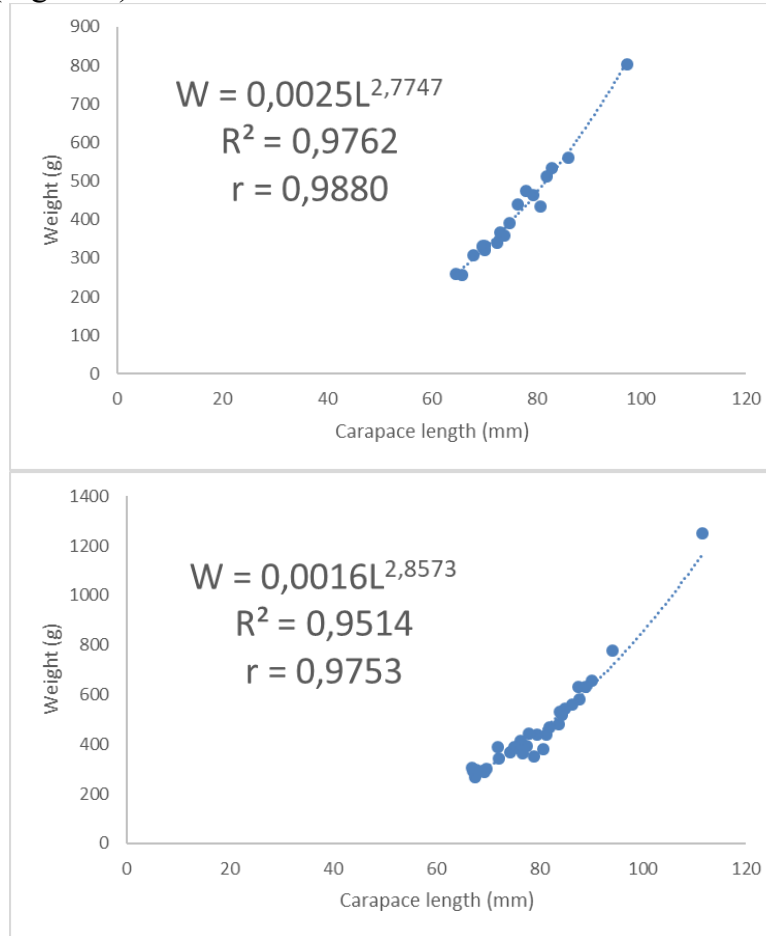

Figure 4. Carapace length-weight correlation of female (above) and male (below) ornate spiny lobster

\subsection{Carapace length at first time ornate spiny lobster catch}

The carapace length size at the first time catch of ornate spiny lobster was obtained by entering the proportion of carapace length in the logistic function equation. The ratio of carapace length at the first time catch was $71.28 \mathrm{mmCL}$ (Figure 4).

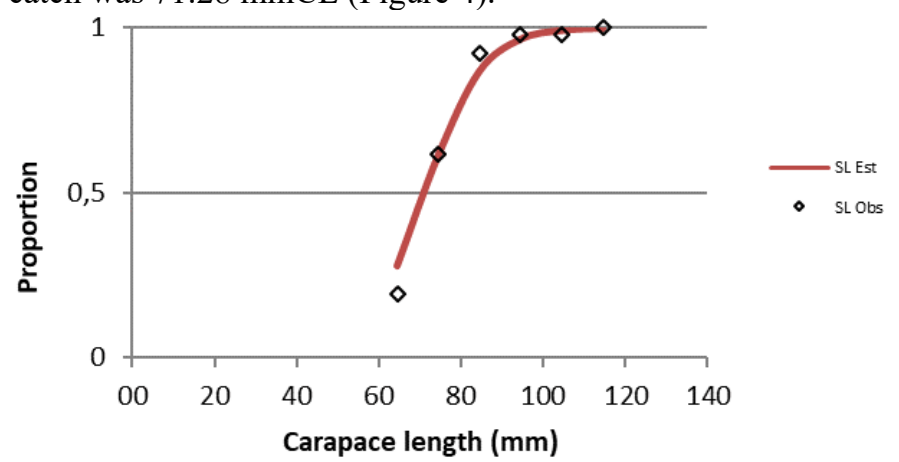

Figure 5. Carapace length at first time ornate spiny lobster catch.

\section{Discussion}

In general, the sexual of ornate spiny lobster can be directly visually identified by identifying the thellicum pairs in male and gonadophore characteristics in female ${ }^{15,22}$. The general expectation of the sex ratio between females and males is 1:1. Male of ornate spiny lobster was found to be more dominant compared to female in Sebatik Island waters. Chi-square $\left(\mathrm{X}^{2}\right)$ test results on the sex ratio show a significant difference $(\mathrm{P}>0.05)$, which means that the ratio between female and male ornate spiny lobster is unbalanced ${ }^{23}$.

The growth pattern of ornate spiny lobster was negatively allometric, so carapace length increases faster than ornate spiny lobster weight. Negative allometric growth patterns of ornate spiny lobster in Sebatik Island waters is possible due to abiotic factors from a high level of pressure from the marine environment where they live, with dominant human activities, functional gonad maturity, and oceanographic processes $^{24,25}$. As a comparison from other research on ornate spiny lobster growth patterns, data from Sorong waters shows a negative allometric pattern ${ }^{26}$. Another lobster species (spiny mud lobster) in Sebatik Island waters data shows negative allometric patterns ${ }^{13}$. Carapace length-weight correlation shows a very high level of correlation $(>0.90)$.

The variance of b-value (as a growth pattern estimator) on the correlation between carapace length and weight of ornate spiny lobster show a relative growth that can change through time affected by environmental conditions. Changes in the environment, food availability, reproduction phase stages, and puberty molting may alter this value. The difference in b-value variance is affected by the dimensions of carapace length and weight levels of each species. Still, it may also be affected by several factors, such as food 
availability, water quality, sexual, gonad maturity level, and habitat well-being $24,25,27,28$.

The difference in carapace length is caused by different fishing pressures and environmental conditions $^{14}$. Lobsters in Sebatik Island waters are caught by traditional fishers with a 6-inch mesh size ${ }^{13}$. Efforts to catch ornate spiny lobster are carried out around the waters near the coast in Sebatik Island to the Ambalat waters to have different depths.

The length at first catch $\left(\mathrm{L}_{\mathrm{c}}\right)$ within a population is generally defined when $50 \%$ of individuals have been caught. The factors that affect the length at first catch value for a crustacean population are fishing pressure and the type of fishing gear used ${ }^{29,30}$. Carapace length size at the first time catch of ornate spiny lobster was $71.28 \mathrm{mmCL}$. The regulation of minimum legal size (MLS) of ornate spiny lobster is an important tool to ensure the sustainability of ornate spiny lobster resources in Sebatik Island waters. In general, Indonesia has set the minimum carapace length regulation through the Marine Affairs and Fisheries Minister Decree No.12/2020 on the minimum legal size for lobster, more than $80 \mathrm{~mm}$ carapace length. More than $50 \%$ of samples were caught by fisherman $<80 \mathrm{~mm}$ carapace length, therefore the MLS regulation in lobster minimum carapace size is not fully applied in Sebatik Island waters. Lobsters with size $>80 \mathrm{mmCL}$ are commonly caught in deeper waters and farther from the coast ${ }^{31}$. It would be more effort for fishermen to reach the site and more cost allowed. MLS recommendation just following the regulation from the government (lobster size $>80 \mathrm{mmCL}$ ) would allow an increased chance for ornate spiny lobster to spawn and increase potential total egg production of these lobster, therefore safeguarding the population productivity and their resilience to crustacean fishing pressure ${ }^{32}$. The consequence of this recommendation is a decrease in the total number of ornate spiny lobster landing and fishermen's income, however, in the long run, this would safeguard the ornate spiny lobster biomass and population, which would provide added value for fishermen income.

\section{Conclusion}

Ornate spiny lobster in Sebatik Island waters based on female-male ornate spiny lobster sex ratio shows an unstable ratio. The carapace length is between 64.6-111.6 mm, distribution from mean carapace length class $64.5-114.5 \mathrm{~mm}$. The class mode of carapace length is found at the class median of $74.5 \mathrm{~mm}$. Growth patterns in both females and males have a negative allometric pattern, while the carapace length-weight correlation shows a very high level of correlation $(>0.90)$. More than $50 \%$ of samples were caught by Sebatik Island fisherman $<80 \mathrm{~mm}$ in carapace length, therefore the minimum legal size (MLS) regulation in lobster minimum carapace length is not fully applied in Sebatik Island waters. By improving the implementation of MLS management in Sebatik Island waters by adopting the MLS recommended by the government, it is hoped that it would contribute to the well-being of fishers and sustainability of fisheries resources, especially for ornate spiny lobster.

\section{References}

1. L. Garibaldi. The FAO global production database: a six-decades effort to catch the trend. Marine Policy. 36(5): 760-768 (2012)

2. J. Keesing, T. Irvine. Coastal biodiversity in the Indian Ocean: the known, the unknown, and the unknowable. Indian Journal of Marine Science. 34: 11-26 (2005)

3. Muzammil W. Studi morfometrik dan meristik udang mantis (Oratosquillina gravieri dan Harpiosquilla raphidea) di daerah pantai berlumpur Kuala Tungkal, Provinsi Jambi [Skripsi]. Institut Pertanian Bogor, Bogor. In Bahasa Indonesia (2010)

4. W. Muzammil, T. Apriadi, W.R. Melani, K.D. Handayani. Length-weight correlations and environmental parameters of Macrobrachium malayanum (J. Roux, 1935) in Senggarang Water Flow, Tanjungpinang City, Riau Islands, Indonesia. Aceh Journal of Animal Science. 5(1): 18-25 (2020)

5. W. Muzammil, T. Apriadi, W.R. Melani, A. Damora. Bio information of blue swimming crab (Portunus pelagicus) during covid-19 pandemic in Bintan District, Riau Islands Province. Jurnal Pengelolaan Perikanan Tropis (Journal of Tropical Fisheries Management), 5(2): (to be published)

6. W. Muzammil, T. Apriadi, W.R. Melani, T.D. Pramesthy, A. Damora. Length and length mature of blue swimming crab (Portunus pelagicus) in Bintan during the covid-19 pandemic. OMNIAKUATIKA Journal of Fisheries and Marine Research (to be published)

7. Beni, Zairion, Y. Wardiatno. Biological aspect of double-spined rock lobster (Panulirus penicillatus) in Wonogiry Regency waters, Central Java, Indonesia. IOP Conf. Ser.: Earth Environ. Sci. 420 012006 (2020)

8. Tirtadanu, A. Suman, U. Chodrijah, B. Kang, C-I Zhang. Stock assessment and management implications of three lobster species in Gunungkidul waters, Indonesia. Ocean \& Coastal Management, 211: 105780 (2021)

9. Y. Wardiatno, A.A. Hakim, A. Mashar, N.A. Butet, L. Adrianto, A. Farajallah. On the presence of the Andaman lobster, Metanephrops andamanicus (Wood-Mason, 1891) (Crustacea Astacidea Nephropidae) in Palabuhanratu bay (S-Java, Indonesia). Biodiversity Journal, 7(1): 17-20 (2016)

10. A. Jeffs. Status and challenges for advancing lobster aquaculture. J. Mar. Biol. Ass. India, 52 (2): 320-326 (2010)

11. C.M. Jones, T. Le Anh, B. Priyambodo. Lobster aquaculture development in Vietnam and Indonesia. In: Radhakrishnan E, Phillips B, Achamveetil G. (eds) Lobster: Biology, Fisheries, 
and Aquaculture. Springer, Singapore. pp 541-570 (2019)

12. M.C. Ooi, E.F. Goulden, G.G. Smith, A.R. Bridle. Hemolymph microbiome of the cultured ornate spiny lobster Panulirus ornatus at different temperatures. Scientific Reports, 9 (1677): $1-13$ (2019)

13. Tirtadanu, U. Chodrijah, K. Wagiyo. Reference point and exploitation status of mud spiny lobster (Panulirus polyphagus Herbst, 1793) in Sebatik waters, Indonesia. Indonesian Fisheries Research Journal, 27 (1): 27-36 (2021)

14. U. Chodrijah, A. Priatna, D. Nugroho. Distribution of length and population parameters of mud spiny lobster (Panulirus polyphagus Herbst, 1793) in Sebatik waters, North Borneo (WPPNRI-716). Jurnal Penelitian Perikanan Indonesia, 24 (1): 1123 (2018)

15. S. Wirosaputro. Kind a sex-ratio of spiny lobster (Panulirus spp.) in Gunungkidul area, Yogyakarta. J. Fish Sci., 1(1): 12-21 (1996)

16. R.G.H. Steel, J.S.H. Torrie. Prinsip dan Prosedur Statistika: Suatu Pendekatan Biometrik (p.748). Terjemahan. Edisi kedua. PT Gramedia Pustaka Utama. Jakarta. In Bahasa Indonesia (1989)

17. S. Jennings, M. Kaiser, J.D. Reynolds. Marine Fisheries Ecology. Alden Press Ltd. Blackwell Publishing. United Kingdom. 417 p (2001)

18. M. King. Fisheries biology: Assessment and Management. Fishing News Books. Oxford, England. 341 p (1995)

19. P. Sparre, S.C. Venema. Introduction to tropical fish stock assessment part 1. Manual. FAO Fish. Tech. Pap. (306/1). Rev.1: 376 p (1992)

20. I.A. Fikri, O.P. Darmono, J.M.S. Tetelepta, A. Damora, W. Muzammil. Risk potency analysis and sustainability status of mud crab Scylla sp. of Sorbay Bay, Southeast Maluku district, Indonesia. IOP Conference Series: Earth and Environmental Science. 216(1), 012038 (2018)

21. F. Yanto, Susiana, W. Muzammil. The utilization rate of brown strip red snapper (Lutjanus vitta) on Mapur waters that landed in Kelong Village, Bintan Pesisir Sub District, Bintan Regency. Journal of Tropical Fisheries Management, 4(2): 1-9 (2020)

22. Yusnaini, M.N. Nessa, M.I. Djawad, D.D. Trijuno. Morphological characteristics of sex and maturity ornate spiny lobster (Panulirus ornatus). Torani: Jurnal Ilmu Kelautan dan Perikanan, 19(3): 166174 (2009)

23. C. Tureli, I. Yesilyurt. Reproductive biology of blue swimming crab, Portunus segnis (Forskal, 1775) in Yumurtalik Cove, Northeastern Mediterranean, Turkey. Mediterranean Marine Science. 18(3): 424-432 (2018)

24. W.A. Saputra, K.A. Pambudi, A. Setyanto, A. Tumulyadi. The differences of depth on the species composition of spiny lobster puerulus on south
Pacitan Regency East Java. IOP Conf. Ser.: Earth and Environmental Science, 441012130 (2020)

25. A. Setyanto, Soemarno, D.G.R. Wiadnya, C. Prayogo. Biodiversity of lobster larvae (Panulirus spp.) from the Indonesian Eastern Indian Ocean. IOP Conf. Ser.: Earth and Environmental Science, 370012046 (2019)

26. Tirtadanu, H.N. Yusuf. Growth parameters and utilization status of ornate spiny lobster (Panulirus ornatus Fabricius, 1798) in Sorong waters, West Papua. Jurnal Penelitian Perikanan Indonesia, 24(2): 87-96 (2018)

27. A. Damora, Y. Wardiatno, L. Adrianto. Catch per unit effort and population parameters of scalloped spiny lobster (Panulirus homarus) in Gunung Kidul Waters. Marine Fisheries, 9(1): 11-24 (2018)

28. J.K. Kizhakudan, S.K. Patel. Size at maturity in the mud spiny lobster Panulirus polyphagus (Herbst, 1793). J. Mar. Biol. Ass. India, 52(2): 170-179 (2010)

29. C. Kunsook, N. Gajaseni, N. Paphavasit. A stock assessment of the blue swimming crab Portunus pelagicus (Linnaeus, 1758) for sustainable management in Kung Krabaen Bay, Gulf of Thailand. Tropical Life Sciences Research. 25(1): 41-59 (2014)

30. Z. Liu, X. Wu, W. Wang, B. Yan, Y. Cheng. Size distribution and monthly variation of ovarian development for the female blue swimmer crab, Portunus pelagicus in Beibu Gulf, off South China. Scientia Marina. 78(2): 257-268 (2014)

31. A. Rahman, D.A. Hedianto, D. Wijaya. Size distribution and condition factors of scalloped spiny lobster (Panulirus homarus Linnaeus 1758) in Pananjung Pangandaran. Widyariset, 4(2): 205-211 (2018)

32. Zairion, Y. Wardiatno, M. Boer, A. Fahrudin. Reproductive biology of the blue swimming crab Portunus pelagicus (Brachyura: Portunidae) in East Lampung Waters, Indonesia: fecundity and reproductive potential. Tropical Life Sciences Research. 26(1): 67-85 (2015) 